\title{
Cihannüma
}

Tarih ve Coğrafya Araştırmaları Dergisi

Say1 V/1 - Temmuz 2019, 165-169

\section{Umberto Eco (Editör), Antik Yakındoğu, (Çeviren: Leyla Tonguç Basmaci), Alfa Yayıncılık, İstanbul 2018, 520 sayfa, 47 resim +9 harita, ISBN: 978-605-171-780-7}

İtalyanların Mezopotamya bölgesindeki ilk arkeolojik kaz1 faaliyetleri Guiseppe Furlani ve Doro Levi önderliğinde 1933 yllında, kuzey Mezopotamya'daki Erbil'in yaklassı 28 kilometre battsinda yer alan bir Asur yerleşimi Kilizu (Kasr Şamamuk)'da başlamıştı. 1930'ların başlarında bu iki İtalyan arkeolog Irak'in o zamana kadar bilinen bazı Sümer, Babil ve Asur yerleșimlerine keşif amaçlı geziler düzenlemişti. İtalyan arkeoloji heyetinin Kilizu'da yaptığ1 çalışmalar çok sayıda zengin buluntunun gün yüzüne çıkmasına neden olmuştu. Ancak buradaki kazı faaliyetleri iki ay gibi oldukça kısa bir süre devam etti. İtalya'daki iç ve dış siyasi gelişmeler ve daha sonrasında patlak veren II. Dünya Savaşı neticesinde buradaki kazı faaliyetlerine devam edilemedi. ${ }^{1}$ Bununla birlikte özellikle 1950’lerde sonra İtalyanların Mezopotamya bölgesinde tekrardan aktif olmaya başladığı görülmektedir. Onların Anadolu'daki benzer bilimsel faaliyetleri de hemen hemen aynı dönemlere denk düşer. 1961 yılından bu yana devam eden ve günümüzde Türk bilim heyetinin de dâhil olduğu farklı disiplinlerden bilim insanlarının bir araya geldiği Melid (Arslantepe) kazıları, ${ }^{2} 1964$ yılında Paolo Matthiae önderliğinde Suriye-Halep şehrinin 60 kilometre güneybatısında yer alan ve Suriye bölgesindeki özellikle M.Ö. 3. bin yıl ile 2 . binin ortalarına kadar varlı̆̆ını güçlü bir şekilde hissettiren krallıklardan birisine (Ebla) ev sahipliği yapan Ebla (Tel Mardik)'da başlatılan kazılar, ${ }^{3}$ Suriye-Humus'un yaklaşık olarak 18 kilometre kuzeybatısında yer alan Orta Tunç Çăğ'nın önemli yerleşim yerlerinden Katna (Tell Mișrife)'da 1999 yılında bașlayan Suriye, Alman ve İtalyan ortak kazı projesi ${ }^{4}$ ve Türkiye- Suriye sınırında yukarı Fırat nehri civarında konumlanan Geç Tunç Çağı ve Demir Çăğ'nın önemli yerleşmelerinden Karkamış kentinde Türk-İtalyan heyetinin yürüttüğü ortak kaz1 (2011-2017) projeleri İtalyan arkeoloji heyetinin Yakındoğu'da yürüttüğü akla ilk gelen önemli bilimsel çalışmalarıdır. ${ }^{5}$

1 Stefano Anastasio, "Assyrian Pottery Between the Middle and Neo-Assyrian Periods: The Case of Qasr Shamamuk", (Editörler: Peter A. Miglus - Simone Mühl), Between the Cultures. The Central Tigris Region from the $3^{\text {rd }}$ to the $1^{\text {st }}$ Millennium BC (HSAO 14), Heidelberg: Heidelberger Orientverlag 2011, 343-345.

2 Malatya'daki Geç Hitit dönemi yerleşimlerinden Arslantepe kazılarının tarihi ve son durumu ile ilgili bakını: http://www.arslantepe.com

3 Paolo Matthiae, "A Long Journey: Fifty Years of Research on the Bronze Age at Tell Mardikh/Ebla", Ebla and Its Landscape, (Editörler: Paolo Matthiae - Nicolo Marchetti), Walnut Creek - California: Left Coast Press, 2013, 35-48.

4 Katna (Qatna) kazılarının tarihi ve son durumu ile ilgili bakınız: http://www.qatna.org

5 Ayrıca İtalyanlar tarafindan gerek Mezopotamya'nın gerekse de Anadolu'nun başka yerlerinde tarih öncesi dönemlerden Ortaçağlara kadar uzanan dönemlerle ilgili yürütülmüş ve halen devam etmekte olan birçok başka proje bulunmaktadır. Türkiye'de kesintisiz bir șekilde düzenlenmeye devam eden ve en son 9-10 Mart 2018'de dokuzuncusu tertiplenen “Türkiye'deki Arkeolojik 


\section{Gökhan Kağnucı}

Mezopotamya bölgesinde yürütülen söz konusu arkeolojik faaliyetler neticesinde özellikle 1950 sonrasında İtalya'daki birçok üniversitede eski Yakındoğu tarihiyle ilgili çalışmalar artış göstermeye başlamıştı. Zaman içerisinde özellikle Suriye'de bulunan Ebla kentindeki kazılardan ele geçirilen çok sayıda çivi yazılı metin ve arkeolojik malzeme etkisiyle eski Yakındoğu tarihi çalışmalarına özgün katkılar sunularak Almanya, İngiltere ve Fransa gibi Avrupa ülkelerinin yanı sıra İtalya'nın da Asur bilimi alanında söz sahibi olması arzulanmıştı. ${ }^{6}$ Son yıllarda eski Yakındoğu arkeolojisi, epigrafisi ve tarihine ilgi ve bu alanlarda yürütülen çalışmalar bu disiplinin kendi içerisinde bir "İtalyan tarzının" akademik bir gelenek halinde sürdürülmeye çalışıldığını göstermektedir. ${ }^{7} \mathrm{Bu}$ çalışmalar hem ilgili akademik camialara hem de Yakındoğu'nun eski tarihi ve arkeolojisine ilgi duyan meslekten olmayan okuyucuya yönelik yayınları da içermektedir. Bu yazıda hakkında bilgi verilecek olan kitap söz konusu ikinci okuyucu kitle açısından uygun bir örnek olarak görülebilir.

Burada hakkında bilgi verilecek 'L' antichità. Le civiltà del Vicino Oriente" orijinal ismiyle ilk olarak İtalyanca yayınlanan ve editörlüğünü 2016 yllında vefat eden ortaçă̆ tarihçisi, roman yazarı ve edebiyat kuramcısı olarak ünlenen Umberto Eco'nun yaptığı kitap, Alfa (Tarih) Yayıncılık tarafından 2018 y1linın ortalarında Leyla Tonguç Basmacı tarafindan Türkçe’ye aktarıldı. Yaklaşık 520 sayfadan ve çok sayıda görselden oluşan Türkçe kitabın hemen hemen çok büyük bir kısmının eski Yakındoğu'nun tarihi konusunda uzman İtalyan arkeolog ve tarihçi tarafindan kaleme alındığı anlaşılmaktadır. ${ }^{8}$ Bu araştırmacıların çok büyük bir kısmı halen faal olarak akademik çalışmalarını yürüten görece genç nesilden oluşmaktadır. Bununla birlikte kitaba yazılarıyla katkıda bulunanlar arasında Mario Liverani, Frederick

Çalışmalara Eğitim, Araştırma ve Kazıda İtalya Katkısı Sempozyumları'nda İtalyanların Anadolu'da yürüttükleri bilimsel çalışmalara dair veriler ilgili akademik camialarla paylaşılmaya devam edilmektedir. Ayrıca "Türkiye'deki Arkeolojik Çalışmalara Eğitim, Araştırma ve Kazı'da İtalya Katkısı" başlıklı Arkeoloji ve Sanat Dergisi'nin 148. özel sayısındaki (2015) İtalyanca-Türkçe çift dilli yayınlar da Anadolu'da yürütülen İtalyan projeleri hakkında güncel haberler içermektedir.

6 İtalya'da Asur bilimi Almanya, İngiltere ve Amerika Birleşik Devletlerinin tersine tıpkı Fransa'da olduğu gibi eski çağ tarihinin bir dalı olarak görülmüştür. Bu alanda uzmanlaşma büyük oranda lisans üstü eğitimle mümkün olmuştur. Bakınız: Dominique Charpin, "How to be an Assyriologist", şurada: https://books.openedition.org/cdf/4924 (ilgili bölüm: 1.2.12).

7 1-2 Mart 2018'de İtalya-Verona Üniversitesinde düzenlenen "I incontro dei Giovani Ricercatori italiani di Assiriologia" başlıklı konferansta bir araya gelen genç İtalyan Asur bilimciler kendi projeleriyle ilgili ileriye dönük fikirlerini tartşstlar. Bakınız: Simonetta Ponchia, Silvia Salin ve Francesca Minen, "First Meeting of Giovani Ricercatori Italiani di Assiriologia (GRIA)", Nouvelles Assyriologiques Brèves et Utilitaires 2018/1, 59-60.

8 Bazı bölümler İtalyan kökenli olmayan araştırmacıların imzasını taşımaktadır. "Imparatorluk Mirası: Keldaniler, Medler ve Persler (M.Ö.600-300)" başlığı altındaki beş bölüm Yeni Babil dönemi ekonomisiyle ilgili çalışmalarıyla bilinen Viyana Üniversitesi'nden Michael Jursa ve "Mürį̌" başlı̆̆1 altındaki 3 bölüm ise İngiltere'deki Cambridge Üniversitesi'nden Graeme Lawson (antikçağ müziği ile ilgili çalışmaları mevcut), Almanya'daki Freie Universität Berlin'den Alexandra von Lieven (eski Mısır tarihi çalısmaktadır) ve Würzburg Üniversitesi’nden Dahlia Shehata (antikçağ müziği ile ilgili yayınları bulunmaktadır) tarafından kaleme alınmışlardır. 
Mario Fales ve Alfonso Archi gibi eski Yakındoğu tarihi ile ilgili çalışmalarıyla tanınan daha eski kuşağa mensup İtalya'nın önde gelen tarihçilerin ve arkeologların yazılarının yer almadı̆̆ı görülmektedir.

Kitap beş ana bölümden oluşmaktadır: Tarih, Görsel Sanatlar, Bilim ve Teknik, Tıp ve Müzik. Ele alınan konuların coğrafi dağılımları Mezopotamya, Mısır, Suriye-Filistin, Anadolu ve İran bölgeleriyle sınırlandırılmıştır. Zaman dilimi olarak ise yaklaşık olarak M.Ö. 8000-4000 arası yani büyük ölçüde Neolitik dönemi içeren dönemle Pers (Akamenid) ve Helenistik (M.Ö.600-300) dönem arası belirlenmiştir.? Devletler arası siyasi-askeri gelişmeler ve ilişkiler, ticari aktiviteler, ekonomik düzenlemeler, sosyo-kültürel yapılar ve unsurlar ile bilim, sanat ve mimari alanlardaki gelişmeler yazıların temel odak noktasını oluşturmaktadır. Bununla birlikte özellikle "Tıp" ve "Müzik" başlıkları altında ele alınan konularda başka coğrafyalardaki söz konusu alanlardaki gelişmelerin de üzerinde durulduğu görülmektedir. "Çin Tibbı”, "Hint Tibbı” ve "Etruria’da Müzik” alt başlıkları buna örnek gösterilebilir. İlk etapta söz konusu başlıklara bu kitapta neden yer ayrıldı̆̆1 anlaşılamasa da, bu konuların eski Yakındoğu tıbbı ve müziği açısından bir "karşılaştırma olanağı" sunmuş oldukları anlaşılacaktır. Bazı yazarların birden fazla alt bölüm kaleme aldığ1 görülmektedir. ${ }^{10}$ Kitabın alana en önemli katkılarından bir tanesi, yazarlarının birçoğunun İtalyan araştırmacılardan oluşması nedeniyle eski Yakındoğu tarihi ve arkeolojisindeki İtalyan merkezli bir bakışın çerçevesinin belirlenmesine olanak sağlamasıdır. ${ }^{11}$

Her ne kadar kitabın kapağında büyük harflerle Umberto Eco'nun editörlüğü vurgusu, (en kötüsünden) bu ismi tanıyanların kitabı eline alıp şöyle bir göz atmasına neden olsa da, eski Yakındoğu tarihi alnında çalışan araştırmacıların aklına ilk olarak Eco'nun kitaba nasıl bir katkı sunmuş olabileceği gelmiş olmalıdır. Açıkçası kitabın başındaki Eco imzalı kısa bir "Antikçağa Giriş" başlıklı yazıda eski Yakındoğu tarihi ve arkeolojisi ile ilgili hiçbir bilginin hatta ifadenin bile yer almaması bu katkının boyutu hakkında bilgi vermektedir. Kendisinin imzasını taşıyan eski Yunan ve Roma antikçağının kültürel ve edebi yönlerinden dem vurduğu bu kısa giriş yazısının her bir satırı yine kendisinin editör olarak görüldüğü

9 Bu zamansal ve mekânsal belirlenim çoğu zaman değişkenlik arz etmektedir. Bakınız: Marc Van De Mieroop, Antik Yakindoğu'nun Taribi (İ.Ö. 3000-323), (Çeviren: Sinem Gül), Dost Kitabevi Yayınlar1: Ankara, 2006, 17-21.

10 Örneğin Roma’daki Sapienza Üniversitesi’nden arkeolog Davide Nadali, “Güzel Sanatlar” başlı̆̆1 altındaki on üç alt bölüme imzasını atmıştır.

11 Alfa Yayıncılığın Tarih serisi altında Türkçe’ye aktarılan benzer bir başka çalışma eski Yakındoğu tarihi alanındaki araştırmalarda Fransız ekolünün/metodolojisinin anlaşılmasına katkıda bulunmuştu. Bakınız: Pierre Bordreuil, Françoise Briquel (Chatonnet) ve Cecile Michel, Taribin Başlangıçlar: Eski Yakindoğu Kültür ve Uygarlıklar, (Çeviren: Levent Başaran), Alfa Yayıncılık: İstanbul, 2015. 


\section{Gökhan Kağncı}

ve Türkçe'ye de çevrilen bir başka kitabın giriş yazısının birebir aynısıdır. ${ }^{12}$ Dolayısıyla kitabın “Giriş” bölümünde eski Yakındoğu’nun artık genel bir kabulü haline gelen "uygarlıkların beşiğì" söyleminden arındırılması gerektiğini tartışarak okuyucuya kitabın içeriği ve yöntemi hakkında kısmen bilgi veren Lucio Milano'nun "editörlüğünün” kitaba dair ifadeleri açısından daha değerli olduğu ifade edilmelidir.

Kitapta ele alınan konuların içeriği ve iç dizaynı ile ilgili göze çarpan ilk şey, ne (alt) bölümlerin sonunda ne de kitabın sonunda herhangi bir kaynakçanın verilmemiş olmasıdır. Metinlerin içerisinde ya da alt kısımlarında başka çalışmalara dair herhangi bir referans verme yoluna gidilmemiş olduğu görülmektedir. Ancak birçok (alt) bölümün sonunda okuyucu, kitapta yer alan diğer bölümlere referanslar verilerek "çapraz okumalara" yönlendirilmiştir. Bu durumun editöryal bir durumundan mı kaynaklandığ1 yoksa okuyucu kitlesini belirleme politikasıyla m1 ilgili olduğu bilinmemektedir. Yazıların içeriğine göz atıldığında ele alınan konularla ilgili bilgilerin çok derinlikli ve analitik nitelikte olmadığı daha ziyade herkesin genel anlamda bilgi sahibi olacağı düzeyde olduğu anlaşılmaktadır. Kitabın orta kısmında (orijinalinde kitabın arkasında verilen) yaklaşık 50 sayfa civarında renkli kuşe kâğıda basılmış arkeolojik alanlarla ilgili resimlerin; çivi yazılı tabletlerin, stellerin, heykellerin, maddi kültür unsurlarının fotoğraflarının ve haritaların okuyucunun anlama düzeyine katkıda bulunacak nitelikte olduğu düşünülebilir. Ayrıca kitabın en arkasında yine renkli bir şekilde kitapta bahsedilen dönemler ve içerikle ilgili birtakım görsellerin bulunduğu eski Yakındoğu kronolojisinin de tablolaştırılmış olduğu görülecektir. Kitabın çevirisinin çok büyük oranda başarılı olduğu ifade edilmelidir. Alanın kavramlarıyla ilgili önemli sayılabilecek çeviri yanlışlarının olmadığ1 söylenebilir. Ancak bazı yerlerde birtakım yazım ve noktalama hatalar1 tespit edilmiştir. ${ }^{13}$ Dizin kısmında bazı önemli kelimelerin eksik olduğu belirlenmiştir. Kitabın orijinalinde (Türkçe çeviride göz önünde bulundurulan EncycloMedia Publishers'in 2017 tarihli baskısına bakılmıştır) herhangi bir dizine rastlanmadığı için Türkçe dizinin belirlenmesinde kısıtlamalara gidilmiş olduğu anlaşılmaktadir.

Sonuç olarak Antik Yakındoğu isimli bu kitap, eski Yakındoğu'da hüküm sürmüş olan devletlerin askeri ve siyasi geçmişleri ile kültürel, bilimsel ve sanatsal faaliyetleri hakkında okuyucuya genel bir fikir vermektedir. Böylece genel olarak M.Ö. 3. ve 1. bin yıllar arasında Yakındoğu'da varlık göstermiş her bir uygarlı̆̆ın kendi iç dinamikleri hakkında bilgi sahibi olunabilmektedir. Ayrıca bu uygarlıkların

12 Çok büyük ihtimalle bu yazı (ilk olarak?) “Antik Yunan” şeklinde Türkçe'ye aktarllan L'Antichità. Grecia isimli kitap için yazılmıştı. Bakınız: Umberto Eco (Ed.), Antik Yunan, (Çeviren: Leyla Tonguç Basmacı), 2. basım, Alfa Yayıncılık: İstanbul, 2018, 13-22.

13 İçindekiler kısmında geçen "Lusia Barbato" (doğrusu: Luisa), sayfa 28'deki “yeterinde” (doğrusu yeterince), sayfa 61'deki başlık "Misır Anadolu'da" (doğrusu Misır ve Anadolu), sayfa 90'daki başlık "Ön Hanedanlar" (tercihen: Erken ya da Er-hanedanlar), sayfa 94'deki "İri-inim-gina" (tercihen: Urukagina) ve sayfa 144'deki "Eştar” (doğrusu: İştar) bunlardan birkaçıdır. 
ve kültürlerin birbirleriyle ilişkileri sayesinde de karşlaş̧ırmalı birtakım sonuçlara varabilmek mümkün olmaktadır. Bununla birlikte bu kitap, eski Yakındoğu tarihi çalışmalarındaki bir "İtalyan tarzının veya metodolojisinin" ipuçlarını göstermesi açısından özgün bir yere sahip olmakla birlikte, Helenistik döneme kadarki süreci "toplu olarak" (kronolojik) ele alan "Eskiçağ' da Yakındoğu ya da Yakındoğu'nun Eskiçağı" temalı Türkçe'deki diğer kitaplardaki (çeviri ve telif) içeriklerden ya da bilgilerden büyük oranda ve farkl1-yeni bir şey sunamamaktadır.

Gökhan Kağnıcı*

* Dr. Öğr. Üyesi, Usak Üniversitesi, Fen-Edebiyat Fakültesi, Tarih Bölümü, İzmir Yolu 8. km Bir Eylül Kampüsü 64200 Uşak/Türkiye gokhan.kagnici@usak.edu.tr 